Indian Journal of Science and Technology

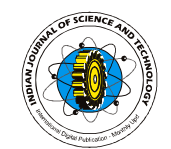

Vol. 5 No. 1 (Jan 2012)

ISSN: 0974- 6846

\title{
Evaluation of deficit irrigation management, nitrogen levels, and seed priming simultaneously, on some properties of hybrid sunflower (Helianthus annuus)
}

\author{
Ali Haji Mohammadi ${ }^{* 1}$, Reza Zarghami ${ }^{2}$, Ali Kashani ${ }^{3}$, Saeede Haji Zade ${ }^{4}$, Ehsan Gholami Saman ${ }^{5}$, Sarvin Nikpouri ${ }^{6}$ \\ ${ }^{1}$ M.Sc in Agronomy, Young Researchers club, Varamin-Pishva Branch, Islamic Azad University, Varamin, Iran. Email: \\ Corresponding E-mail address: Hajimohammadi.ali.1388@gmail.com \\ ${ }^{2}$ Assistant Prof, Member of scientific board of Agricultural Biotechnology Research Institute, Karaj, Iran. \\ Email:Rezazarghami2001@yahoo.com \\ ${ }^{3}$ Professor in Agronomy, Faculty of Agriculture, Karaj Branch, Islamic Azad University, Karaj, Iran. Email: \\ Alro_kaschani@yahoo.de \\ ${ }^{4}$ M.Sc in Agronomy, Department of Agronomy and Plant Breeding, Shahid Bahonar University of Kerman, Kerman, \\ Iran. \\ ${ }^{5}$ Department of management, Ghaemshahr Branch, Islamic Azad University, Ghaemshahr, Iran \\ ${ }^{6}$ Young Researchers club, North Tehran Branch, Islamic Azad University, Tehran, Iran.
}

\begin{abstract}
Sunflower (Helianthus annuus L.), one of the world's leading oilseed crops, was investigated for its properties in response to deficit irrigation, nitrogen levels, and seed priming. The end points were: Biological yield, oil yield and water use efficiency (WUE). For this purpose, a randomized block experiment design with split-split plot arrangement with four replicates was established. The overall results obtained in this study indicate that different level of nitrogen, time of irrigation, seed priming and their interaction had significantly affected on biological yield and WUE ( $p \leq 0.01)$. Also, different level of nitrogen and time of irrigation had significantly affected on biological yield ( $P \leq 0.05$ and $p \leq 0.01)$, respectively. But, seed priming and their interactions had no significant effect on this trait. Treatment of ${ }_{4} \mathrm{~N}_{3} \mathrm{Pt}_{3}$ had the most WUE $\left(3.02 \mathrm{~kg} / \mathrm{m}^{3}\right)$. Pre-treatment mono ethanol amine had the most effect on biological yield. The using of mono ethanol amine in $\mathrm{I}_{4} \mathrm{Pt}_{3}$ could prevent the decrease of biological yield (from 40.21 to $7.43 \%$ ) due to drought stress in comparison with $\mathrm{I}_{4} \mathrm{Pt}_{1}$. Investigation of project's results shows that pre-treated sunflower plant by mono ethanol amine decrease the damages but it to be repeated by more researches for better announcement.
\end{abstract}

Keywords: biological yield, Nitrogen, oil yield, Sunflower, Water use efficiency (WUE).

Introduction

Sunflower (Helianthus annuus L.), one of the world's leading oilseed crops, is mainly cultivated for its oil. Nonoilseed sunflower (confectionary) with lower oil content is mainly consumed in the domestic market, such as in snack or bakery foods (Goksoy et al., 2004; Kiani et al., 2007). Like most oilseeds, sunflower has a potential utility for many industries. Different products can be obtained from crude oil, cake, hulls or refined oil, including plastics, lecithin, or emulsifying agents (Taiz \& Ezeiger, 1991; Aguirrezábal \& Pereyra, 1998). In the last few years, sunflower oil has also gained special recognition based on non-food purposes. Its use as biodiesel, or as vegetable-oil based fuel for many vehicles, including farming equipment is feasible (Pereyra-Irujo et al., 2009). Genetic improvement and the emergence of new industrial processes make it possible to implement these potential uses. Most of the oil is accumulated in the kernel (shelled seed) and only 3-5\% is located in the pericap, also known as "hull" (Connor \& Sadras, 1992). The oil concentration is determined by genetic factors, but it can be modified by the environment and growth conditions. Usually, black hull hybrids produce fruit (seeds) with an oil concentration higher than striped hull hybrids (Izquierdo et al., 2008). It is common to find mixture of hybrids (seeds of black and striped hull) as feeding in the dehulling process. In order to improve equipment handling and to optimize oil yield, it would be necessary to know the differential characteristics of these hybrids. A few reports on moisture-dependent physical properties of sunflower seeds have been published. Gupta and Das (1997) analyzed the physical properties of a sunflower variety grown in India (Morden) (Gupta \& Das, 1997), (Santalla \& Mascheroni 2003) studied a striated high oleic sunflower hybrid cultivated in Argentina, but no bibliography has been found about a comparison among sunflower hybrids of different structural characteristics (Santalla \& Mascheroni, 2003). Irrigation is one of the most important limiting factors of the agricultural production during the hot and dry periods (Dagdelen et al., 2006). Sunflower oil contains large amount of $A, D, E$, $\mathrm{K}$ vitamins and considerable proteins (20-40\%) (Connor \& Hall, 1997; Aerts \& Chapin, 2000). By fertilizing and increasing the soil fertility, the seed yield and its oil content are increased (Egli, 1998; Sudhakar et al., 2003; Sharma et al., 2002). Simultaneous decrease of oil percentage and increase of nitrogen levels have been reported by many researchers (Tomar et al., 1997; Janssen, 1998).The present study aims for evaluation on deficit irrigation, nitrogen levels, and seed priming simultaneously for hybrid sunflower (Helianthus annuus). The properties evaluated were: Biological yield, oil yield and Water use efficiency (WUE).

Materials and methods

A randomized block experiment design with split-split plot arrangement with four replicates was established in
Research article

CIndian Society for Education and Environment (iSee)
"Yield response of sunflower" http://www.indjst.org
A.H.Mohammadi Indian J.Sci.Technol. 
the research farm of the Islamic Azad University, Varamin-Pishva branch, Tehran, Iran. Each plot included 7 planting lines (distance between lines was $60 \mathrm{~cm}$ ), length of each line was $2 \mathrm{~m}$ and also distance in-row was $20 \mathrm{~cm}$. The soil was classified in loam-clay. After soil experiment, seeds were planted in two depths include $0-30 \mathrm{~cm}$ and $30-60 \mathrm{~cm}$ as furrower method and then were irrigated immediately. Protections were achieved accordance routine agronomic methods. All treatments were irrigated three times in order to homozygous germination and the used water was calculated by contour during the growth season. In

Table1. Characteristics of irrigation treatments

\begin{tabular}{|c|c|c|}
\hline Treatment & No. of irrigation & Used water $\left(\mathrm{m}^{3} / \mathrm{ha}\right)$ \\
\hline $\mathrm{I}_{1}$ & 13 & 8563.492 \\
\hline $\mathrm{I}_{2}$ & 11 & 7246.031 \\
\hline $\mathrm{I}_{3}$ & 11 & 7246.371 \\
\hline $\mathrm{I}_{4}$ & 9 & 5928.571 \\
\hline
\end{tabular}

order to calculation of irrigation depth, soil samples selected from depths $0-30$ and $30-60 \mathrm{~cm}$. the humidity percentage of soil was calculated and then the needed water to reach to field capacity was measured. Also soil
Table 3. Variance analysis on measured characters (MS)

\begin{tabular}{|c|c|c|c|c|}
\hline S.O.V & df & $\begin{array}{c}\text { Biological } \\
\text { Yield (kg/ha) }\end{array}$ & $\begin{array}{l}\text { Oil yield } \\
(\mathrm{Kg} / \mathrm{ha})\end{array}$ & $\begin{array}{c}\text { Water use } \\
\text { efficiency } \\
\left(\mathrm{kg} / \mathrm{m}^{3}\right)\end{array}$ \\
\hline $\mathrm{R}$ & 3 & 2637743.065 & 131301.331 & 0.045 \\
\hline I & 3 & $191956786.446 * *$ & $1865236.24^{\star \star}$ & $0.434^{* *}$ \\
\hline $\mathrm{a}$ & 9 & 2483046.533 & 43165.118 & 0.049 \\
\hline $\mathrm{N}$ & 2 & $71345681.993^{* *}$ & $950517.747^{*}$ & $1.364^{* *}$ \\
\hline I.N & 6 & $50160267.999^{\star *}$ & $167783.811 \mathrm{~ns}$ & $0.964^{* *}$ \\
\hline $\mathrm{b}$ & 24 & 6361546.406 & 220653.337 & 0.144 \\
\hline $\mathrm{Pt}$ & 2 & $43824071.066^{* *}$ & $215682.451 \mathrm{~ns}$ & $1.153^{* *}$ \\
\hline I.Pt & 6 & $47975140.160^{\star *}$ & $127179.568 \mathrm{~ns}$ & $0.945^{\star *}$ \\
\hline N.Pt & 4 & $28709921.177^{\star *}$ & $227202.863 \mathrm{~ns}$ & $0.698^{* *}$ \\
\hline I.N.Pt & 12 & $27002002.628^{\star *}$ & $132377.605 \mathrm{~ns}$ & $0.614^{* *}$ \\
\hline C & 72 & 8798054.510 & 115937.489 & 0.168 \\
\hline c.v\% & - & 20.58 & 24.57 & 20.62 \\
\hline
\end{tabular}

trend of shoot weight (stalk, leaf and head), leaf area and photosynthesis crops production resulted from limited water during phonologic stages (Table 4). Also, trend of changes shows that biological yield in treatment of $\mathrm{I}_{2}$ was decreased $6.42 \%$ in comparison to $I_{1}$. Also biological yield in treatment of $\mathrm{I}_{3}$ and $\mathrm{I}_{4}$ was decreased $15.43 \%$ and

Table 2. Meteorological properties of studied area

\begin{tabular}{|l|l|l|l|l|l|l|l|l|}
\hline $\begin{array}{l}\text { Wind speed } \\
(\mathrm{km} / \mathrm{hr})\end{array}$ & $\begin{array}{l}\text { Evaporation } \\
(\mathrm{mm})\end{array}$ & $\begin{array}{l}\text { rainfall } \\
(\mathrm{mm})\end{array}$ & $\begin{array}{l}\mathrm{RH} \\
(\%)\end{array}$ & $\begin{array}{l}\text { Sun hours } \\
\text { (Hour) }\end{array}$ & $\begin{array}{l}\text { Min mean } \\
\text { temperature }\left({ }^{\circ} \mathrm{C}\right)\end{array}$ & $\begin{array}{l}\text { Max mean } \\
\text { temperature }\left({ }^{\circ} \mathrm{C}\right)\end{array}$ & $\begin{array}{l}\text { Annual mean } \\
\text { temperature }\left({ }^{\circ} \mathrm{C}\right)\end{array}$ & factors \\
\hline 12.16 & 292.16 & 1.13 & 33.16 & 318.66 & 18.35 & 34.63 & 26.5 & mean \\
\hline
\end{tabular}

was fertilized with nitrogen fertilizer in two times include pre-planting (1/3) and post-thinning (2/3).

Experimental treatments include irrigation levels in four levels:

$\mathrm{I}_{1}$ : perfect irrigation, $\mathrm{I}_{2}$ : no irrigation from budding to flowering, $I_{3}$ : no irrigation from flowering to grain filling and $\mathrm{I}_{4}$ : no irrigation from budding to grain filling stage as main factor (drought stress in phonological stages of plant) and used nitrogen in three levels of 0,90 and 180 $\mathrm{kg} / \mathrm{ha}$ as marginal factor.

Seed priming in three levels of $\mathrm{Pt}_{1}$ : no pre-treatment, $\mathrm{Pt}_{2}$ : soaking seeds in distilled water for 24 hours and $\mathrm{Pt}_{3}$ : soaking seeds in mono ethanol amine for 6 hours as subsub factor.

Water used and times of irrigation show in Table 1. Some meteorological properties of studied area show in Table 2. The properties evaluated in this study were biological and oil yield and water use efficiency. The data obtained from field measurements and laboratory observations were collected to analysis with statistical comparison of averages, using the Duncan's multiple range test method with MSTATC software.

\section{Results and discussion}

Biological yield

According to Table 3, different level of nitrogen, time of irrigation, seed priming and their interaction had significantly affected on biological yield with confidence interval of $99 \%(p \leq 0.01)$. Also, minimum and maximum amount of biological yield was obtained in ${ }_{4} \mathrm{~N}_{1} \mathrm{Pt}_{2}$ and $\mathrm{I}_{2} \mathrm{~N}_{1} \mathrm{Pt}_{3}$ treatment, respectively that implied decreasing Research article (C)Indian Society for Education and Environment (iSee)
$31.95 \%$ in comparison to $I_{1}$, respectively. With increasing the used nitrogen (from 90 to $180 \mathrm{~kg} / \mathrm{ha}$ ) biological yield was increased too.Similar letters show there isn't any significant difference between treatments

Oil yield

Grain oil yield is one of the most important traits in sunflower (grain oil yield= grain oil percentage * grain yield). Obtained results from Table 3 show that different level of nitrogen and time of irrigation had significantly affected on oil yield with confidence interval of $95 \%$ and 99\% ( $\mathrm{P} \leq 0.05$ and $\mathrm{p} \leq 0.01)$, respectively. But, seed priming and their interactions had no significant effect on this trait. The maximum and minimum amount of oil yield (2003 and $713.51 \mathrm{~kg} / \mathrm{ha}$ ) achieved in $\mathrm{I}_{1} \mathrm{~N}_{3} \mathrm{Pt}_{1}$ and $\mathrm{I}_{4} \mathrm{~N}_{1} \mathrm{Pt}_{1}$ treatments, respectively. Oil yield in $\mathrm{I}_{2}$ increased $5.46 \%$ toward $I_{3}$. Also, minimum and maximum amount of oil yield achieved in 0 and $180 \mathrm{~kg} \mathrm{~N} / \mathrm{ha}$.

\section{Water use efficiency (WUE)}

According to Table 3, different level of nitrogen, time of irrigation, seed priming and their interaction had significantly affected on WUE with confidence interval of $99 \%(p \leq 0.01)$. The maximum WUE were obtained in $\mathrm{I}_{4} \mathrm{~N}_{3} \mathrm{Pt}_{3}\left(3.02 \mathrm{~kg} / \mathrm{m}^{3}\right), \mathrm{I}_{2} \mathrm{~N}_{3} \mathrm{Pt}_{3}\left(2.80 \mathrm{~kg} / \mathrm{m}^{3}\right)$ and $\mathrm{I}_{3} \mathrm{~N}_{2} \mathrm{Pt}_{3}$ $\left(2.78 \mathrm{~kg} / \mathrm{m}^{3}\right)$ whereas, the lowest WUE $\left(1.18 \mathrm{~kg} / \mathrm{m}^{3}\right)$ have been reported in ${ }_{4} \mathrm{~N}_{3} \mathrm{Pt}_{2}$ (Table. 4).

\section{Conclusion}

The overall results obtained in this study indicate that different level of nitrogen, time of irrigation, seed priming and their interaction had significantly affected on biological yield and WUE with confidence interval of $99 \%$ "Yield response of sunflower" http://www.indjst.org
A.H.Mohammadi Indian J.Sci.Technol. 
$(p \leq 0.01)$. Also, different level of nitrogen and time of irrigation had significantly affected on biological yield with confidence interval of $95 \%$ and $99 \%$ ( $P \leq 0.05$ and $p \leq 0.01)$, respectively. But, seed priming and their interactions had no significant effect on this trait. Also, results showed that simultaneously utilizing the $\mathrm{N}_{3}$ (180 $\mathrm{kg} / \mathrm{ha}$ ) and $\mathrm{I}_{1}$ resulted to decreasing of damage on yield in comparison with other treatments in sunflower. $\mathrm{I}_{4} \mathrm{~N}_{3} \mathrm{Pt}_{3}$

Table 4. The effects of triple interaction treatments on measured characters

\begin{tabular}{|c|c|c|c|}
\hline Factor & $\begin{array}{l}\text { Biological } \\
\text { Yield (kg/ha) }\end{array}$ & $\begin{array}{l}\text { Oil yield } \\
\text { (Kg/ha) }\end{array}$ & $\begin{array}{c}\text { Water use } \\
\text { efficiency }\left(\mathrm{kg} / \mathrm{m}^{3}\right)\end{array}$ \\
\hline I1NOPt1 & 16740 ABCDEFG & 1261.BCDEFGHI & 2.160 BCDEFGH \\
\hline I1N0Pt2 & 17290 ABCDEF & 1380BCDEFGH & $2.232 \mathrm{BCDEFGH}$ \\
\hline I1N0Pt3 & 13700CDEFGHIJ & 1373BCDEFGH & 2.009 DEFGHI \\
\hline I1N90Pt1 & $18710 \mathrm{ABC}$ & 1598.ABCDEF & 2.184BCDEFGH \\
\hline I1N90Pt2 & 14770 BCDEFGHI & 1330BCDEFGH & 1.725 EFGHIJK \\
\hline I1N90Pt3 & 13890 CDEFGHIJ & 1505 ABCDEF & 1.621 GHIJK \\
\hline I1N180Pt1 & 18490ABCD & 2003.A & 1.955 DEFGHI \\
\hline I1N180Pt2 & $19110 \mathrm{AB}$ & 1990.A & 2.019 DEFGHI \\
\hline I1N180Pt3 & 17200ABCDEFG & 1510.ABCDEF & $1.599 \mathrm{HIJK}$ \\
\hline I2NOPt1 & 13510 DEFGHIJK & 1451.ABCDEF & 1.828 EFGHIJK \\
\hline I2NOPt2 & 16150ABCDEFGH & 1405.BCDEFG & $2.767 \mathrm{ABC}$ \\
\hline I2NOPt3 & $20300 \mathrm{~A}$ & 1716.ABC & 2.322 BCDEFG \\
\hline I2N90Pt1 & 14920 BCDEFGHI & 1504.ABCDEF & 2.060 DEFGHI \\
\hline I2N90Pt2 & 13050EFGHIJK & 1496.ABCDEF & 1.800 EFGHIJK \\
\hline I2N90Pt3 & 12190 FGHIJK & 1480.ABCDEF & 1.682 FGHIJK \\
\hline 2N180Pt1 & 13250 EFGHIJK & 1720.ABC & 1.865 DEFGHIJK \\
\hline I2N180Pt2 & $20050 \mathrm{~A}$ & 1382BCDEFGH & $2.229 \mathrm{BCDEFGH}$ \\
\hline I2N180Pt3 & 16830ABCDEFG & 1747.AB & $2.802 \mathrm{AB}$ \\
\hline I3NOPt1 & $8850 \mathrm{JKL}$ & 1061EFGHI & 2.007 DEFGHI \\
\hline I3NOPt2 & 10160 IJKL & 1247BCDEFGHI & 1.904 DEFGHIJ \\
\hline I3N0Pt3 & 11570 HIJKL & 1142CDEFGHI & $2.545 \mathrm{ABCD}$ \\
\hline I3N90Pt1 & 12270 FGHIJK & 1306BCDEFGH & 1.693 FGHIJK \\
\hline I3N90Pt2 & 16940ABCDEFG & 1431ABCDEFG & 2.337 BCDEF \\
\hline I3N90Pt3 & $20140 \mathrm{~A}$ & 1665ABCD & $2.780 \mathrm{ABC}$ \\
\hline I3N180Pt1 & 14550 BCDEFGHI & 1654ABCDE & $1.221 \mathrm{JK}$ \\
\hline I3N180Pt2 & 13800 CDEFGHIJ & 1375BCDEFGH & $1.403 \mathrm{IJK}$ \\
\hline I3N180Pt3 & 18440ABCD & 1585ABCDEF & $1.596 \mathrm{HIJK}$ \\
\hline 14NOPt1 & $8479 \mathrm{KL}$ & 713.51 & 1.900 DEFGHIJ \\
\hline 14N0Pt2 & $7048 \mathrm{~L}$ & $849.3 \mathrm{GHI}$ & 2.045 DEFGHI \\
\hline 14N0Pt3 & 17950ABCDE & 1553.ABCDEF & $2.429 \mathrm{ABCDE}$ \\
\hline I4N90Pt1 & 12500 FGHIJK & 1101DEFGHI & $2.108 \mathrm{CDEFGHI}$ \\
\hline 14N90Pt2 & $9124 \mathrm{JKL}$ & $810.5 \mathrm{HI}$ & $1.539 \mathrm{HIJK}$ \\
\hline 14N90Pt3 & 9113JKL & 1045FGHI & 1.537 HIJK \\
\hline 14N180Pt1 & 11260HIJKL & 1186BCDEFGHI & $1.430 \mathrm{IJK}$ \\
\hline 14N180Pt2 & 12120 GHIJK & 1171.BCDEFGHI & $1.189 \mathrm{~K}$ \\
\hline 14N180Pt3 & 14400 BCDEFGHI & 1150BCDEFGHI & $3.027 \mathrm{~A}$ \\
\hline
\end{tabular}

had the most WUE $\left(3.02 \mathrm{~kg} / \mathrm{m}^{3}\right)$. Pre-treatment mono ethanol amine had the most effect on biological yield. The using of mono ethanol amine in $\mathrm{I}_{4} \mathrm{Pt}_{3}$ could prevent the decrease of biological yield (from 40.21 to $7.43 \%$ ) due to drought stress in comparison with $\mathrm{I}_{4} \mathrm{Pt}_{1}$. Investigation of pOroject's results shows that pre-treated sunflower plant by mono ethanol amine decrease the damages but it to be repeated by more researches for better announcement.

\section{References}

1. Aerts R and Chapin FSI (2000) The mineral nutrition of wild plants revisited: a re-evaluation of processes and patterns. Adv. Ecol. Res. 30, 1-67.

Research article

CCIndian Society for Education and Environment (iSee)
"Yield response of sunflower" http://www.indjst.org
2. Aguirrezábal LAN and Pereyra VR (1998) Girasol. En Facultad de Ciencias Agrarias (UNMdP) e Instituto Nacional de Tecnología Agropecuaria (Eds.), Calidad de Productos Agrícolas. Bases ecofisiológicas, genéticas y de manejo agronómico, Balcarce, Argentina. 140-196.

3. Connor DJ and Sadras VO (1992) Physiology of yield expression in sunflower, Field Crops Res. 30, 333-389.

4. Connor DJ and Hall AJ (1997) Sunflower Physiology. In: Sunflower technology and production. Schneiter AA (Ed.), American Society of Agronomy: Madison, WI, USA. pp:113-182.

5. Dagdelen N, Yilmaz E, Sezgin F and Gurbuz T (2006) Water-yield relation and water use efficiency of cotton (Gossypium hirsutum L.) and second crop corn (Zea mays L.) in western Turkey. Agri. Water Management. 82, 63-85.

6. Egli DG (1998) Seed biology and the yield of grain crops. (Cab Internet: New York).

7. Goksoy AT Demir AO Turan ZM and Dagustu N (2004) Responses of sunflower to full and limited irrigation at different growth stages. Field Crops Res. 87, 167-178.

8. Gupta RK and Das SK (1997) Physical properties of sunflower seeds. J. Agri. Engg. Res. 66, 1-8.

9. Izquierdo N, Dosio GAA, Cantarero $M$ and Aguirrezábal LAN (2008) Weight per grain, oil concentration and solar radiation intercepted during grain filling in black hull and stripped hull sunflower hybrids. Crop Sci. 48, 688-699.

10. Janssen B.H (1998) Efficient use of nutrients: an art of balancing. Field Crops Res. 56, 197201.

11. Kiani PS, Hewezi P, Gentzbittle $L$ and Sarrafi A (2007) Genetic variability for physiological traits under drought conditions and differential expression of water stress-associated genes in sunflower (Helianthus annuus L.) Theoretical \& Appl. Genetics, 114, 193-207.

12. Pereyra-Irujo GA, Izquierdo NG, Covi M, Nolasco SM, Quiroz F and Aguirrezábal LAN (2009) Variability in sunflower oil quality for biodiesel production: a simulation study. Biomass \& Bioenergy. 33, 459-468.

13. Santalla EM, and Mascheroni RH (2003) Physical properties of high oleic sunflower seeds, Food Sci. \& Technol. Intl. 9 (6), 435-438.

14. Sharma OP and Gupta AK (2002) Nitrogenphosphorus nutrition of pearl millet as influenced by intercrop legumes and fertilizer levels. J. Plant Nutr. 25, 12-23.

15. Sudhakar G, Solaimalai A and Ravisankar N (2003) Influence of cultivars and levels of nitrogen on yield, nutrient uptake and residual nutrient status of soil in semi dry rice. Agric. Sci. Digest. 23, 88-91.

16. Taiz L and Zeiger E (1991) Plant physiology. Benjamin Cummings publ. company, California U.S.A. pp:346-356.

17. Tomar HPS, Sigh HP and Dadhwal KS (1997) Effect of irrigation, nitrogen and phosphorus on grown and yield of spring sunflower. Indian J. Agronomy. 42 (1), 169-172.
A.H.Mohammadi Indian J.Sci.Technol. 